\title{
Sensor Technology in the Netherlands: \\ State of the Art
}

Proceedings of the Dutch Sensor Conference held at the University of Twente, The Netherlands, 2-3 March 1998

Edited by
A. van den Berg
and
P. Bergveld
MESA Research Institute,
University of Twente,
The Netherlands

SPRINGER-SCIENCE+BUSINESS MEDIA, B.V. 
A C.I.P. Catalogue record for this book is available from the Library of Congress.

ISBN 978-94-010-6103-2 ISBN 978-94-011-5010-1 (eBook)

DOI 10.1007/978-94-011-5010-1

Printed on acid-free paper

All Rights reserved

(C)1998 Springer Science+Business Media Dordrecht

Originally published by Kluwer Academic Publishers in 1998

Softcover reprint of the hardcover 1st edition 1998

No part of the material protected by this copyright notice may be reproduced or utilized

in any form or by any means, electronic or mechanical, including photocopying, recording or by any information storage and retrieval system, without written permission from the copyright owner. 


\section{Preface}

The 1998 Dutch Sensor Conference held on March 2-3, 1998, at the University of Twente in Enschede, the Netherlands is the third in a series of biannual meetings. The series of conferences is initiated by the Dutch Technology Foundation (STW) in order to stimulate the industrial application of scientific sensor research. The main reason for this has been the fact that in spite of a very long and outstanding reputation on high quality sensor research, few products have been marketed in the Netherlands up to now. This sensor conference not only offers academic and industrial researchers an opportunity to present the latest results of research and development on sensors, actuators and microsystems, but in addition offers designers and developers from industry inspiration for new products and gives them the chance to meet young researchers.

In this second MESA Monograph the Proceedings of the third National Sensor Conference are collected. It contains both a collection of the latest research and development results from all major Dutch centers for sensor research, as well as several contributions on the aspects of sensor commercialization, as presented at the conference as (invited or submitted)oral or poster contributions. Thus, it provides an excellent overview of the state of the art of Dutch Sensor Technology in 1998, which explains the title of this Monograph volume. In addition we invited two Swiss researchers to present their view on sensor development in the field of biochemical sensor systems and the utilization of new micromechanical sensing principles for chemical sensor(arrays).

At this place I would like to acknowledge the contributions of the programme committee, the local organizing committee, STW, the sponsors, many MESA members and, last but not least the contributing authors.
Albert van den Berg
Conference chairman. 


\section{Programme Committee}

A. van den Berg (University of Twente (MESA), chairman)

P. Bergveld (University of Twente (MESA))

W. Olthuis (University of Twente (MESA))

R. Wolffenbuttel (Delft University of Technology (DIMES))

G. Meier (Delft University of Technology, DIMES)

H. Leeuwis (3T BV)

A.J. Kölling (Texas Instruments)

Sponsors

\section{in TEXAS \\ INSTRUMENTS \\ Texas Instruments}

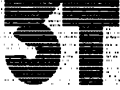

3T BV

ald

1. In Mkrol'ser:

vace

Twente MicroProducts 


\section{Contents}

MEASUREMENT STRATEGIES FOR OBJECT IDENTIFICATION

P.P.L. Regtien

A SMART 2.5D IMAGE SENSOR CONTAINING A PSD ARRAY AND AN

ON-CHIP MULTIPLEXER

M. de Bakker, P.W. Verbeek and G.K. Steenvoorden

ADAPTIVE OPTICAL SYSTEM BASED ON A MICROMACHINED

ADAPTIVE MIRROR

G. Vdovin, S. Sakarya

THE INTEGRATED COMPASS WATCH MICROSYSTEM

R.J.W.T. Tangelder, H.G. Kerkhoff

NON-DESTRUCTIVE FOOD-STERILITY AND PACKAGE-QUALITY

TESTING OF ASEPTICALLY PACKED FOOD PRODUCTS BY IMPEDANCE MEASUREMENTS

S.N. Nihtianov, G.C.M. Meijer

TRANSDUCTION PRINCIPLES AND INTEGRATION OF CHEMICAL SENSORS INTO A MICROMECHANICAL ARRAY DEVICE

R. Berger, H.P. Lang, J.P. Ramseyer, F. Battiston, J.H. Fabian, L. Scandella,

C. Andreoli, J. Brügger, M. Despont, P. Vettiger, E. Meyer, H.-J. Güntherodt,

Ch. Berger, J.K. Gimzewski

MEASUREMENT ON SINGLE DNA MOLECULES

B.G. de Grooth, A. Agronskaya, Bennink, S.J.T. van Noort, K.O. van der Werf,

J. Greve

NOVEL INTEGRATED OPTICAL REFRACTOMETER

G.J. Veldhuis, P.V. Lambeck

TEMPERATURE DEPENDENCE OF A THERMAL ACCELEROMETER

U.A. Dauderstädt, P.M. Sarro, P.J. French

NEARLY QUANTUM-LIMITED SQUIDS FOR A GRAVITATIONAL WAVE ANTENNA

J. Flokstra, E. Bartolomé, G.K. van Ancum, M.J. van Duuren, H. Rogalla

FROM BIOSENSORS TO BIOSENSING SYSTEMS

E. Verpoorte

GLASS CHANNELS AND CAPILLARY INJECTORS FOR CAPILLARY ZONE ELECTROPHORESIS

$Y$. Fintschenko, V. Spiering, J. van der Moolen, G-J. Burger, A. van den Berg 
R.E. Oosterbroek, J.W. Berenschot, S. Schlautmann, T.S.J. Lammerink, A. van den Berg,

M.C. Elwenspoek

A SYSTEM FOR FLUID DOSING IN THE NANOLITER RANGE

S. Böhm, D. Pijanowska, W. Olthuis, P. Bergveld

CHEMICALLY MODIFIED FIELD-EFFECT TRANSISTORS FOR MEASUREMENT OF ION ACTIVITIES IN AQUEOUS SOLUTION M.M.G. Antonisse, R.J.W. Lugtenberg, A. Ion, R.J.M. Egberink,

B.H.M. Snellink-Ruël, J.F.J. Engbersen, D.N. Reinhoudt

SELECTIVE OPTODE MEMBRANES FOR HEAVY METAL ION DETECTION

N.J. van der Veen, R.J.M. Egberink, J.F.J. Engbersen, D. Reinhoudt

COVALENT COUPLING OF POLYAMINES TO AMINOBEAD-COVERED ISFETS

G. Besselink, G. Dirks, W. Olthuis, P. Bergveld

DNA BINDING KINETICS OF Oct-1 LINKER MUTANT PROTEINS STUDIED WITH THE INSTRUMENT FOR BIOMOLECULAR INTERACTION SENSING (IBIS)

H.C. van Leeuwen, P.C. van der Vliet, R.B.M. Schasfoort

ENTREPRENEURSHIP IN SENSOR-LAND

S. Middelhoek

A NOVEL CONCEPT IN THIN FILM MAGNETIC HEADS:

THE SENSOR LAST DESIGN

A.H. van Heeren, C.W.M.P. Sillen, F.A. Pronk, L. Postma

MEMBRANE FABRICATION WITH GALVANIC ETCH-STOP

C.M.A. Ashruf, E.L. Oemar, P.J. French, P.M. Sarro, P.M.M.C. Bressers, J.J. Kelly

FABRICATION TECHNOLOGY OF GEIGER MODE AVALANCHE PHOTODIODES

W.J. Kindt, H.W. van Zeijl

DRY RELEASE OF METAL STRUCTURES IN OXYGEN PLASMA M. Bartek, S.H. Kong, R.F. Wolffenbuttel

MINIATURIZED ISFET INTERFACE FOR THE USE ON A SERIAL PC PORT

G.R. Langereis, W. Olthuis, P. Bergveld 

ECHO SIGNALS

E.A. Dijkstra, W. Olthuis, J. Holsheimer, P. Bergveld

DESIGN OF A SMART MICROACOUSTIC LIQUID SENSOR SYSTEM 165 PART I: MICROACOUSTIC DEVICE

B. Jakoby, G.W. Lubking, M.J. Vellekoop

DESIGN OF A SMART MICROACOUSTIC LIQUID SENSOR SYSTEM -

PART II: ELECTRONICS

G.W. Lubking, B. Jakoby, M.J. Vellekoop

INFLUENCE OF SUBSTRATE VOLTAGE ON SENSITIVITY AND OFFSET OF (SPINNING-CURRENT) HALL PLATES

S. Bellekom

HYBRID INTEGRATED ELECTRO-OPTIC SENSOR PLATFORM

A.J.T. de Krijger, K.W. Benoist, J.A.G. van Bezooijen, H.H.P.Th. Bekman

A THEORETICAL AND EXPERIMENTAL STUDY OF THE PIEZOJUNCTION EFFECT IN SILICON AND ITS EXPLOITATION IN NEW SENSOR STRUCTURES

F. Fruett, F. Creemer, G.C.M. Meijer, P.J. French

SACRIFICIAL OXIDE ETCHING COMPATIBLE WITH ALUMINIUM METALLIZATION

P.T.J. Gennissen, P.J. French

FREE STANDING BEAMS MADE BY SINGLE STEP ELECTROCHEMICAL 201 ETCHING IN HYDROFLUORIC ACID

H.Ohji, P.J. Trimp, P.J. French

DEVELOPMENT OF A DISPOSABLE BIOSENSOR CHIPCARD SYSTEM

G. Dirks, G. Besselink, W. Olthuis, P. Bergveld

QUARTZ-TO-SILICON FUSION BONDING FOR MICRO ACOUSTIC WAVE APPLICATIONS

A. Berthold, P.M. Sarro, M.J. Vellekoop

CYCLODEXTRINS AS RECEPTORS ON SURFACE ACOUSTIC WAVE DEVICES

H.F.M. Nelissen, M.R. de Jong, F. Venema, M.C. Feiters, R.J.M. Nolte

A LOW-COST SMART INTERFACE FOR ACTIVE SENSORS

X. Li, G.C.M. Meijer

SMART OPTICAL SENSOR SYSTEMS IN CMOS FOR MEASURING LIGHT INTENSITY AND COLOUR

G. de Graaf, R.F. Wolffenbuttel 

FILMS

D. Wijngaards, M. Bartek, R.F. Wolffenbuttel

A FAST AND ACCURATE TEMPERATURE-CONTROL SYSTEM USING SMART TEMPERATURE SENSORS

P.R. van der Meer, G.C.M. Meijer, M.J. Vellekoop, H.M.M. Kerkvliet, T.J.J. van den Boom

AN ACTUATION PRINCIPLE: THE ELECTROLYSIS OF WATER

A MIXER BASED ON DIFFUSION-MIXING DESIGNED FOR THE MAFIASPROJECT

T.T. Veenstra, T.S.J. Lammerink, A. van den Berg, M. Elwenspoek

LOW POWER SIGMA-DELTA ANALOG-TO-DIGITAL CONVERTER INTERFACE FOR BIOMEDICAL MEASUREMENT SYSTEM M. Djurica, J.H. Huijsing

DEVELOPMENT OF CRYOGENIC CURRENT COMPARATORS WITH DC SQUID READOUT FOR THE CALIBRATION OF ELECTRICAL STANDARDS

L. Vargas, G.C.S. Brons, B. Bouverat, J. Flokstra, H. Rogalla, G.Rietveld,

C. Rillo, J. Sesé, A. Camón, W. Jaszczuk and H. Altenburg

SQUID READOUT OF CRYOGENIC PARTICLE DETECTORS

A.W. Hamster, M.J. van Duuren, G.C.S. Brons, J. Flokstra, H. Rogalla

LOW CREEP AND HYSTERESIS LOAD CELL BASED ON A FORCE

TO LIQUID PRESSURE TRANSFORMATION

R.A.F. Zwijze, R.J. Wiegerink, T.S.J. Lammerink, M. Elwenspoek

STABILITY AND APPLICATIONS OF ELECTROCHEMICALLY-ACTIVE SELF-ASSEMBLED MONOLAYERS

M.W.J. Beulen, F.C.J.M. van Veggel, D.N. Reinhoudt

BINDING OF METAL IONS TO SELF-ASSEMBLED MONOLAYERS OF CROWN ETHERS

S. Flink, F.C.J.M. van Veggel, D.N. Reinhoudt

FUNCTIONALIZED CYCLODEXTRIN-CALIX[4]ARENE HOST MOLECULES FOR DETECTION OF ORGANIC ANALYTES 

OF MOLECULAR INTERACTIONS VIA SURFACE PLASMON RESONANCE A. Friggeri, F.C.J.M. van Veggel, D.N. Reinhoudt

BATTERY-LESS SENSORS FOR CONTINUOUS MEASUREMENT OF PHYSIOLOGICAL PARAMETERS OF ANIMALS

W.J. Eradus

AUTHORS INDEX 